\title{
Thirteen new weeds on Cedros Island, Baja California, Mexico
}

\section{Trece malezas nuevas en Isla Cedros, Baja California, México}

\section{Acta Botanica Mexicana}

\author{
Sula E. Vanderplank1,2,3 (iD, Jon P. Rebman² (iD)
}

\begin{abstract}
:
Background and Aims: Cedros Island is the southernmost outpost of the California Floristic Province, the largest island in the Californian archipelago, and home to a suite of endemic plants and animals. As such, it is an important resource within the Pacific Islands Biosphere Reserve, with many management concerns. The goal of this study was to document newly arrived plant species on Cedros Island, Baja California, Mexico.

Methods: From the $8^{\text {th }}$ to the $11^{\text {th }}$ February 2019 we visited Cedros Island and made observations of plants around Cedros Village using the platform NaturaLista (iNaturalist).

Key results: Thirteen new plant taxa were detected around Cedros village, all were non-native. These discoveries follow a very recently published checklist on the flora and suggest that new non-native plants are arriving rapidly.

Conclusions: Recommended management implications include monitoring and eradication of new species, particularly at inhabited areas, and with priority given to highly invasive species such as Cenchrus setaceus and C. ciliaris.
\end{abstract}

Key words: biosecurity, Cenchrus, eradication, invasive flora, Island Cedros.

\section{Resumen:}

Antecedentes y Objetivos: Isla Cedros es el límite sur de la Provincia Florística de California, la isla más grande en el archipiélago californiano, y hogar de varias plantas y animales endémicos. Como tal es un recurso importante dentro de la Reserva de la Biosfera Islas del Pacífico de la Península de Baja California con muchos desafíos de manejo. El objetivo de este estudio es documentar las especies de plantas recién llegadas a Isla Cedros, Baja California, México.

Métodos: Entre el 8 y el 11 de febrero 2019, visitamos la Isla Cedros e hicimos observaciones usando la plataforma NaturaLista (iNaturalist).

Resultados clave: Trece nuevos taxa de plantas fueron detectados cerca del pueblo de Cedros, y todos eran no-nativos. Estos descubrimientos siguen la muy reciente publicación de un listado florístico, sugiriendo que las nuevas especies no-nativas son de reciente establecimiento.

Conclusiones: Las implicaciones recomendadas para el manejo de la isla incluyen el monitoreo y la erradicación de estas especies nuevas, particularmente en áreas habitadas, dando prioridad a las especies más invasivas como Cenchrus setaceus y C. ciliaris.

Palabras clave: bioseguridad, Cenchrus, erradicación, flora invasiva, Isla Cedros.

${ }^{1}$ Pronatura Noroeste, Calle Décima Núm. 60, esq. Ryerson, Zona Centro, 22800 Ensenada, Mexico.

${ }^{2}$ San Diego Natural History Museum, 1788 El Prado, 92101 San Diego, CA, USA.

${ }^{3}$ Author for correspondence: svanderplank@pronatura-noroeste.org
Received: November 17, 2020. Reviewed: December 15, 2020.

Accepted by Marie-Stéphanie Samain: March 20, 2021.

Published Online first: April 15, 2021.

Published: Acta Botanica Mexicana 128 (2021).
To cite as: Vanderplank, E. and J. P. Rebman. 2021. Thirteen new weeds on Cedros Island, Baja California, Mexico. Acta Botanica Mexicana 128: e1823. DOI: https://doi.org/10.21829/abm128.2021.1823 


\section{Introduction}

Cedros Island is the largest island in the Californian archipelago, which includes the eight California Channel Islands and the eight Baja California Pacific Islands (Ratay et al., 2014). It includes 135 square miles $\left(350 \mathrm{~km}^{2}\right)$ of rugged terrain and is located at the southern end of the archipelago, at $28^{\circ} \mathrm{N}$ of latitude (Vanderplank et al., 2017). It is considered to be the southernmost extreme of the California Floristic Province, with north-facing slopes that are home to pine forests and chaparral (Burge et al., 2016). The closest land at Punta Eugenia on the Baja California Peninsula is just 15 miles $(22 \mathrm{~km}$ ) away. Visitors arrive by boat and by airplane, with a landing strip just outside the village.
In 2016 the Mexican government decreed the Pacific Island Biosphere Reserve (DOF, 2016). Cedros is the most biodiverse of the islands in the reserve, with a fauna of 14 reptiles, five terrestrial mammals, and one amphibian (Vanderplank et al., 2017). Much of the island is included in the nuclear zone of the Biosphere Reserve where impacts and activities are restricted, but the village is part of the zone of multiple uses. The village is home to 2000 people and is located in the sheltered southeastern corner of the island (Fig. 1). Thirty-two island endemic plants and animals occur here (Vanderplank et al., 2017), yet invasive species are a conservation challenge, especially in disturbed areas (Fig. 2).

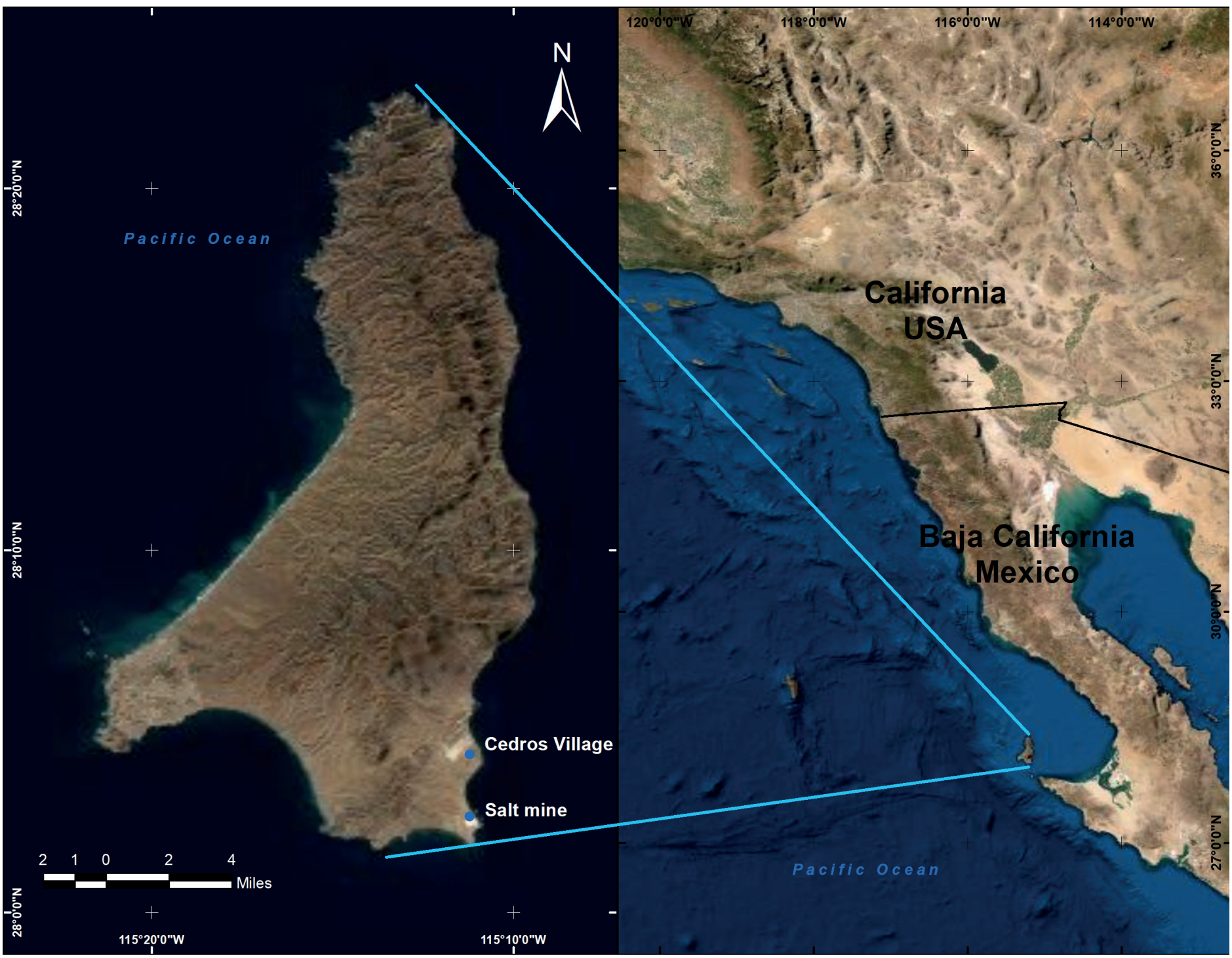

Figure 1: Map of Cedros Island, Baja California, Mexico. 


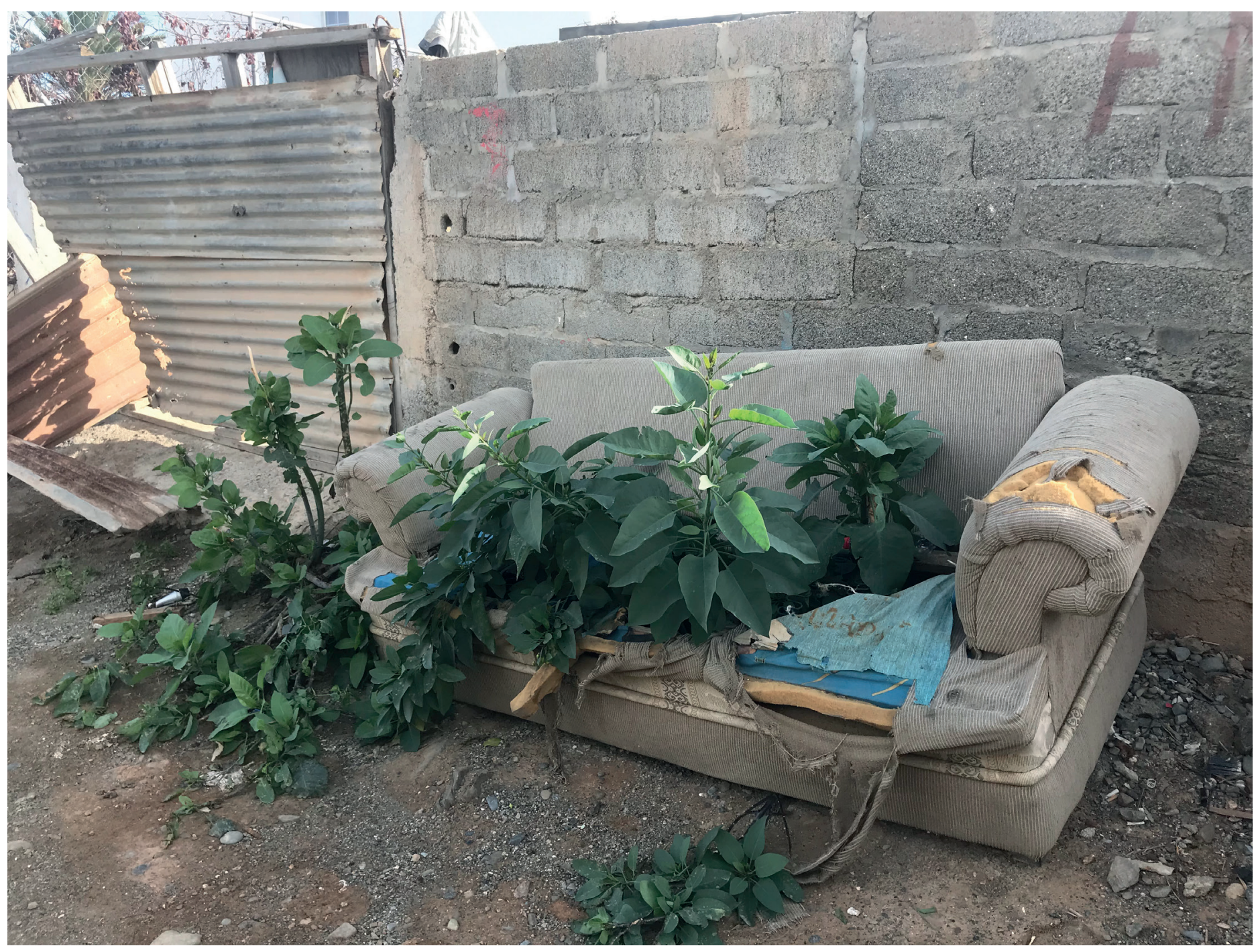

Figure 2: Nicotiana glauca Graham (an invasive plant) growing in a disturbed area near Cedros Village, Baja California, Mexico.

In 2018, Vanderplank et al. published updated vascular plant checklists for the Baja California Pacific Islands, which documented 307 plants on Cedros Island, including 256 native plants, 51 non-native plants and 15 single-island endemic plants. The goal of this study was to document newly arrived plant species on Cedros Island, Baja California, Mexico.

\section{Materials and Methods}

From the $8^{\text {th }}$ to $11^{\text {th }}$ February 2019 , we visited Cedros Island. We explored selected sites on the southern end of the island and walked around Cedros village and the adjacent drainages, including the town dump and the area adjacent to the airstrip. We targeted areas around the village where plants were growing without irrigation, as we assumed these to be the most likely areas for new plant taxa to arrive with human travel to the island. We were not able to collect voucher specimens as we had not secured the necessary permits, so we documented these new records photographically, using the cameras on our cell phones (iPhone 7, USA). For all the plant taxa we encountered that were not on the published checklist, we took photographs during the visit (see date-specific records below) which were later uploaded to iNaturalist, approximately four days after our initial departure from the island (iNaturalist, 2019), a citizen science platform that allows expert identification and assigns accession numbers to individual records (the iNaturalist platform in Mexico is NaturaLista). We were careful to 
photograph diagnostic features, allowing the reliable identification of each taxon. Our total time spent in the field was approximately four hours.

\section{Results}

We documented a total of 13 new records for Cedros Island (Fig. 3), all of which were non-native plants. The new records for the island include five families, and 12 genera, but add only ten new genera to the island's flora (in bold). A summary of the new records is presented in Table 1 , more detailed annotations follow for each taxon.

\section{iNaturalist observations examined}

Malephora crocea (Jacq.) Schwantes (Aizoaceae): only one individual seen that was naturalized outside of an ornamental planting in the CONANP (Comisión Nacional de Áreas Naturales Protegidas) greenhouse area. MEXICO. Baja California, Ensenada municipality, Cedros Island, 28.056595, -115.1906, 8.II.2019, J. Rebman (username: JRebman, ID: 20284748). Cal-IPC (2021) Rating: Watch (meaning this species has been assessed as posing a high risk of becoming invasive in the future in California.) Fig. 3A.

Mesembryanthemum cordifolium L.f. (Aizoaceae): only one patch of naturalized plants was seen at the bottom of a canyon in the vicinity of the town that had escaped from some plantings on the hillsides above. MEXICO. Baja California, Ensenada municipality, Cedros Island, 28.094106, -115.186447, 10.II.2019, J. Rebman (username: JRebman, ID: 20295645). Cal-IPC (2021) Rating: Alert (meaning this species has high or moderate impacts that have limited distribution in California, but may have the potential to spread much further.) Fig. 3B.

Bidens pilosa L. (Asteraceae): approximately three different plants seen in wetter places along fences and walls within the town. MEXICO. Baja California, Ensenada municipality, Cedros Island, 28.100742, -115.187135, 8.II.2019, J. Rebman (username: JRebman, ID: 20228575). Migratory Status in Malezas de México (CONABIO, 2021): native. Fig. 3C.

Helianthus annuus L. (Asteraceae): about five different plants were found in the dump area. MEXICO. Baja California, Ensenada municipality, Cedros Island, 28.071948, -115.219744, 11.II.2019, 8.II.2019, J. Rebman (username: JRebman, ID: 20295240). Migratory Status in Malezas de México (CONABIO, 2021): native. Fig. 3D.

Lactuca serriola L. (Asteraceae): approximately four different vegetative plants seen in wetter places along fences and walls within the town. MEXICO. Baja California, Ensena-

Table 1: New non-native records for Cedros Island, Baja California, Mexico. Newly recorded genera are indicated in bold.

\begin{tabular}{|c|c|c|c|c|}
\hline Family & Genus & Specific epithet & Authors & Infraname \\
\hline Aizoaceae & Malephora & crocea & (Jacq.) Schwantes & \\
\hline Aizoaceae & Mesembryanthemum & cordifolium & L.f. & \\
\hline Asteraceae & Bidens & pilosa & L. & \\
\hline Asteraceae & Helianthus & annuus & L. & \\
\hline Asteraceae & Lactuca & serriola & L. & \\
\hline Chenopodiaceae & Bassia & hyssopifolia & (Pall.) Kuntze & \\
\hline Malvaceae & Gossypium & hirsutum & L. & \\
\hline Poaceae & Bromus & catharticus & Vahl & \\
\hline Poaceae & Cenchrus & ciliaris & $\mathrm{L}$. & \\
\hline Poaceae & Cenchrus & setaceus & (Forssk.) Morrone & \\
\hline Poaceae & Dactyloctenium & aegyptium & (L.) Willd. & \\
\hline Poaceae & Diplachne & fusca & (L.) Roem. \& Schult. & var. uninervia (J. Presl) P.M. Peterson \& N. Snow \\
\hline Poaceae & Phalaris & minor & Retz. & \\
\hline
\end{tabular}



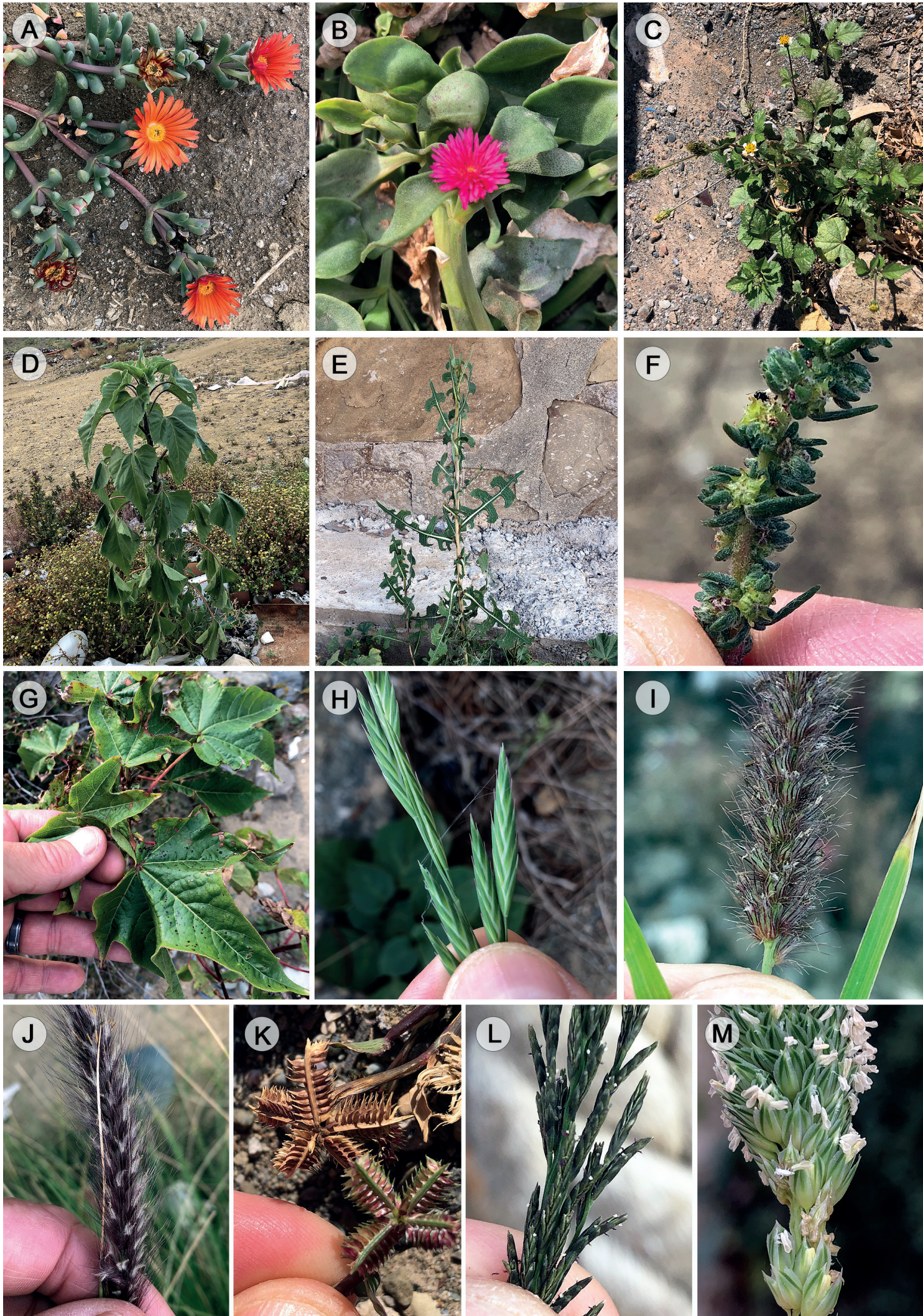

Figure 3: Photos of thirteen new weeds for Cedros Island, Baja California, Mexico. A. Malephora crocea (Jacq.) Schwantes (Aizoaceae); B. Mesembryanthemum cordifolium L.f. (Aizoaceae); C. Bidens pilosa L. (Asteraceae); D. Helianthus annuus L. (Asteraceae); E. Lactuca serriola L. (Asteraceae); F. Bassia hyssopifolia (Pall.) Kuntze (Chenopodiaceae); G. Gossypium hirsutum L. (Malvaceae); H. Bromus catharticus Vahl. (Poaceae); I. Cenchrus ciliaris L. (Poaceae); J. Cenchrus setaceus (Forssk.) Morrone (Poaceae); K. Dactyloctenium aegyptium (L.) Willd. (Poaceae); L. Diplachne fusca (L.) Roem. \& Schult. var. uninervia (J. Presl) P.M. Peterson \& N. Snow (Poaceae); M. Phalaris minor Retz. (Poaceae). Note that these field photos taken by J. Rebman and even more photos for each observation from the island can be viewed on iNaturalist (iNaturalist, 2019). 
da municipality, Cedros Island, 28.098262, -115.187018, 10.Il.2019, J. Rebman (username: JRebman, ID: 20295576). Migratory Status in Malezas de México (CONABIO, 2021): exotic. Fig. 3E.

Bassia hyssopifolia (Pall.) Kuntze (Chenopodiaceae): various individuals of this species were seen in two different alkaline depressions near the airport. MEXICO. Baja California, Ensenada municipality, Cedros Island, 28.043172, -115.191795, 11.II.2019, J. Rebman (username: JRebman, ID: 20296395). Cal-IPC (2021) Rating: Limited (meaning this species is invasive but the ecological impacts are minor. Ecological amplitude and distribution are generally limited, but these species may be locally persistent and problematic.) Fig. 3F.

Gossypium hirsutum L. (Malvaceae): only one large, naturalized, fruiting individual was seen near the bottom of a canyon in the vicinity of the town, that had escaped from some ornamental plantings on the hillsides above. MEXICO. Baja California, Ensenada municipality, Cedros Island, 28.092808, -115.189946, 10.II.2019, J. Rebman (username JRebman, ID: 20296371). Fig. 3G.

Bromus catharticus Vahl (Poaceae): we found several individuals of this grass scattered throughout the vicinity of the town. MEXICO. Baja California, Ensenada municipality, Cedros Island, 28.094071, -115.186102, 10.II.2019, J. Rebman (username: JRebman, ID: 20295661) and 28.044017, -115.191682, 11.II.2019, S. Vanderplank (username sulavanderplank, ID: 20340162). Migratory Status in Malezas de México (CONABIO, 2021): exotic. Fig. 3H.

Cenchrus ciliaris L. (Poaceae): a small population in the dump area with approximately 10 individuals. This species should be prioritized for extirpation due to its highly invasive nature. MEXICO. Baja California, Ensenada municipality, Cedros Island, 28.079262, -115.211634, 8.II.2019, J. Rebman (username: JRebman, ID: 20295269). Migratory Status in Malezas de México (CONABIO, 2021): exotic. Fig. 31.

Cenchrus setaceus (Forssk.) Morrone (Poaceae): only one individual was observed in a wet area near some orna- mental plantings at the airport. This species should be prioritized for extirpation due to its highly invasive nature. MEXICO. Baja California, Ensenada municipality, Cedros Island, 28.043987, -115.191611, 11.II.2019, J. Rebman (username: JRebman, ID: 20296386). Cal-IPC (2021) Rating: Moderate (meaning this species has substantial and apparent-but generally not severe-ecological impacts on physical processes, plant and animal communities, and vegetation structure.) Fig. 3J.

Dactyloctenium aegyptium (L.) Willd. (Poaceae): only one individual seen just outside of the Sportfishing hotel. MEXICO. Baja California, Ensenada municipality, Cedros Island, 28.100676, -115.18715, 8.II.2019, J. Rebman (username: JRebman, ID: 20255127). Migratory Status in Malezas de México (CONABIO, 2021): exotic. Fig. 3K.

Diplachne fusca (L.) Roem. \& Schult. var. uninervia (J. Presl) P.M. Peterson \& N. Snow. (Poaceae): although this species may be native to the peninsula, it appears to be introduced on the island. We found one population with approximately 15 individuals of this species in an alkaline depression near the airport. MEXICO. Baja California, Ensenada municipality, Cedros Island, 28.043238, -115.191528, 11.II.2019, S. Vanderplank (username: sulavanderplank, ID: 20340165). Fig. 3L.

Phalaris minor Retz. (Poaceae): seen along road in a deep ditch area with Brassica tournefortii Gouan, Polygonum argyrocoleon Kunze, and Malva parviflora L. in the dump area. We also found a small population on the lower slopes of a canyon near the town with a road running along the bottom of the road. MEXICO. Baja California, Ensenada Municipality, Cedros Island, 28.093036, -115.188555, 10.Il.2019, J. Rebman (username: JRebman, ID: 20296307); 28.076628, -115.212241, 8.II.2019, J. Rebman (username: JRebman, ID: 20295261). Migratory Status in Malezas de México (CONABIO, 2021): exotic. Fig. 3M.

\section{Discussion}

The thirteen species we encountered are all recent introductions to Cedros Island and for this reason we consider them to be weeds or non-native plants defined as species 
introduced to the region after European contact and as a direct or indirect result of human activity (Cal-IPC, 2021). Not all are invasive. We have indicated the registered status of each species in Malezas de Mexico (CONABIO, 2021) and Cal-IPC (2021) when they were listed. Notably, several of these species are native in other regions of Mexico, but very recent arrivals to the island and not considered native there. Of primary concern are the two Cenchrus L. species, which the authors consider to be particularly problematic on islands.

While we do not generally support the publication of species data in the absence of a voucher specimen, we here report our photo-vouchers in order to make the community aware of these recent arrivals, while there is still a chance for them to be eradicated before their presence is extensive. In 2018 we published updated checklists for the Baja California Pacific Islands, including Cedros Island (Vanderplank et al., 2018), and none of these plants had been documented or reported, suggesting that they are all recent arrivals. However, rainfall had been ample and growing conditions for vascular plants were ideal during our 2019 visit. It is possible that some of these plants were dormant in the soil as seeds until that spring.

We strongly recommend swift management intervention, particularly in the case of Cenchrus setaceus and C. ciliaris (Poaceae) which are both highly invasive. Future biosecurity efforts should include monitoring for aggressive invaders such as these Cenchrus species.

\section{Author contributions}

SV and JR conducted the fieldwork together, JR identified the species, SV wrote the manuscript.

\section{Funding}

We are grateful to the San Diego Natural History Museum, the San Diego Zoo Global, and the Los Angeles Zoo, for the funding and general operating support that made this fieldwork possible.

\section{Acknowledgements}

We are extremely grateful to Isaías Benitez Castro, José Francisco Bareño Gutierrez, and Dilia Rebeca Meza Castro from CONANP (Comisión Nacional de Áreas Naturales Pro- tegidas) who accompanied us in the field and kindly facilitated vehicles and access.

\section{Literature cited}

Burge, D. O., J. H. Thorne, S. P. Harrison, B. C. O’Brien, J. P. Rebman, J. R. Shevock, E. R. Alverson, L. K. Hardison, J. Delgadillo, S. A. Junak, T. A. Oberbauer, H. Riemann, S. E. Vanderplank and T. Barry. 2016. Plant Diversity and Endemism in the California Floristic Province. Madroño 63(2): 3-206. DOI: https://doi.org/10.3120/madr-63-02-3-206.1

Cal-IPC. 2021. The Cal-IPC Inventory. California Invasive Plant Council. Berkeley, USA. https://www.cal-ipc.org/ (consulted January, 2021).

CONABIO. 2021. Malezas de México. Comisión Nacional para el Conocimiento y Uso de la Biodiversidad. Cd. Mx., Mexico. http://www.conabio.gob.mx/malezasdemexico/2inicio/ home-malezas-mexico.htm (consulted January, 2021).

DOF. 2016. Decreto por el que se declara Área Natural Protegida, con el carácter de reserva de la biosfera, la región conocida como Islas del Pacifico de la Península de Baja California. Diario Oficial de la Federación 7 de diciembre de 2016 (Segunda Sección), 52-84. https://www.dof.gob.mx/nota_detalle.php?codigo $=5464451 \&$ fecha $=07 / 12 / 2016$ (consulted November, 2020).

iNaturalist. 2019. iNaturalist. https://www.inaturalist.org/home (consulted March, 2019).

Ratay, S., S. E. Vanderplank and B. Wilder. 2014. Baja California Contributions to the Flora of the Channel Islands. Western North American Naturalist 7: 161-220.

Vanderplank, S. E., J. P. Rebman and E. Ezcurra. 2018. Revised and Updated Vascular Plant Checklists for the Baja California Northern Pacific Islands. Western North American Naturalist 78(4): 674-698. DOI: https://doi.org/10.3398/064.078.0410 Vanderplank, S., A. Peralta García, J. Valdez Villavicencio and C. de la Rosa. 2017. Plantas y animales únicos de las islas del Pacífico de Baja California/Unique Plants and Animals of the Baja California Pacific Islands. Botanical Research Institute of Texas. Fort Worth, USA. 134 pp. 